\title{
Albert Martin* \\ A Plea for a Behavioural Approach in the Science of Human Resources Management ${ }^{* *}$
}

The aim of science is to develop true theories. From this it follows quite naturally that the Behavioural Approach is the only plausible approach in a Science of Human Resources Management. The Behavioural Approach derives its propositions from the best theories from the social and behavioural sciences. It is problem-oriented in the strictest sense and thus escapes discipline-specific narrow-mindedness. It integrates the knowledge bases necessary for good practice. The behavioural approach to human resources management is a success story, it leads to numerous new and far reaching insights.

Key words: Behavioural Sciences, Rational Choice, Philosophy of Science, Critical Rationalism, Instrumentalism

Prof. Dr. Albert Martin, Institute of Business Administration, University of Lueneburg, Campus, D - 21391 Lueneburg, Germany, Phone: ++49-4131-782130.

E-Mail: martin@uni-lueneburg.de.

** Article received: February 26, 2004

Revised version accepted after double blind review: April 24, 2004. 
If not insights into human behaviour, what else could inspire a Science about Human Resources Management? After all, Human Resources Management (HRM) is concerned with human labour. ${ }^{1}$ So to talk about a behavioural approach in a Science of Human Resources Management (HRMS) 2 is an obvious use of tautology. What then could be the content of an article about a behavioural approach in HRMS? One possibility were an explanation of the behavioural concept itself; another to reflect upon the demarcation between the behavioural and other approaches within HRMS. In the following I deal primarily with the former. The latter will be considered only exemplarily whenever it is necessary to discuss some fundamental problems of scientific methodology. ${ }^{3}$

\section{Characteristics of a behavioural HRMS}

The behavioural approach in HRMS (as suggested by the author) is characterized by the following programmatic orientations:

- it deals with fundamental problems about work, work relations and work arrangements, and investigates concrete phenomena of the work life in natural settings,

- it pursues explanations according to the methodology of Critical Rationalism,

- it derives its propositions from the best theories in the social and behavioural sciences.

The following arguments speak for the behavioural approach to human resources management (and thereby against alternative approaches):

- the embodiment of the behavioural approach in realism, (which is a characteristic of the behavioural approach), avoids an improper instrumentalism,

- the behavioural approach to human resource management is problem-oriented and therewith escapes sterile discipline-specific localism,

- questions about work relations are complex questions, the answers to these questions require a broad knowledge. The behavioural approach integrates the necessary knowledge base.

The results of research under the behavioural approach show great promise. The behavioural approach to human resources management is a success story. It leads to numerous new and far reaching insights. The behavioural approach delivers a good knowledge base for improving the conditions of human life and work. And finally, the behavioural approach to human resources management possesses great potential for

1 And with the ways to organize and utilize it.

2 I use the acronym HRMS (Human Resources Management Science) to make a clear distinction between the scientific propositions about the phenomena which characterize human labour, its organization and utilization and the phenomena of human labour itself. It should be noted that the practical efforts to deal with problems of labour in organizations, e.g. Human Resource Management (HRM) is only a (small) part of the reality with which HRMS is confronted.

3 Elements of the behavioural approach can be found in the work of many colleagues even if they do not explicitly comment on this issue, c.f. in the German literature: Schanz (2000), Klimecki/Gmür (1998), Staehle/Conrad/Sydow (1999). For a discussion of different theoretical orientations: c.f. Weber (1996), Festing et al. (2004). 
enlightenment, i.e. behavioural research corrects prejudices and it identifies and criticizes inappropriate ideological claims.

\section{Methodological Positions}

The above theses are based on the methodology of critical rationalism. You can hardly find a position that has had to bear more criticism. Opponents frequently display strong emotions against it, (sometimes abhorrence), whilst adherents have developed the conviction that many of the ideas of Karl Popper, (the father of critical rationalism), have become obsolete - thanks to their active help, (c.f. Böhm/Holweg/Hoock 2002). One can look at this ironically, because it shows a kind of self-reference of critical rationalism. But the situation remains unclear because there is no consent as to the core of critical rationalism. Hans Albert writes: "I myself identify the following central components of critical rationalism: critical realism, consequent fallibilism and methodological revisionism or criticism, but this is only a rough and insufficient answer that is in need of a precise clarification" (Albert 2002, 4). The present author fully agrees with these positions which cannot be treated at full length here. Only one aspect, namely realism, will be discussed. It is in a sense the basic element of critical rationalism, and interestingly enough even this central element of any science is discredited in influential HRMS approaches. Often the disclaiming attitude towards realism is justified by the very nature of the research object of HRMS itself. Sometimes the argument concerning the inherent complexity of the research field is used. Both positions will be discussed.

\subsection{True Science}

The main argument for a behavioural approach to HRMS is as simple as it is convincing: it is that human labour cannot be detached from the person who is working. Every science that deals with the human "factor of production" has to be a behavioural science. This holds at least if HRMS is to be understood as a "true science", (in the sense as explained, for example, by Popper (1962)). But even this seemingly selfevident premise is called frequently into question, (at least in the German debate). It may sound surprising, but many researchers actually think of the aspiration to develop true theories as an outmoded idea. The reasons for this are very diverse. Constructivists maintain that an objective reality does not exist, they see social life as the result of constantly new (re-) constructions formed of changing players and therefore the notion of a true theory has to be refuted, (c.f. Dettmann 1999; Rusch 2002). Similarly, proponents of system theoretic thinking have no ambition to develop general and factually true theories. Instead they use empirical proposition as a means to demonstrate general system theoretic insights, (Lenk 1978; Probst 1993). Structuralists ignore the importance of realistic theories too. Their plea is to develop formal schemes for which applications in "reality" have to be, (and surely will be), found, (Sneed 1971; Schneider 1987). Even the mainstream in economic tradition does not claim to paint with its theories a true picture of reality. The economic understanding of the products of its science has an explicitly instrumentalist meaning, (c.f. Caldwell 1982; Meyer 2002). Instrumentalists deny that the theoretic concepts they use have any counterpart in the real world. Their theories, too, are not intended to represent real processes. Their scientific concepts are used just for analytical purposes. Theories are seen as useful fic- 
tions, which are more or less suitable to make accurate predictions. Milton Friedman argues, for example, that the more unrealistic the premises of a theory, the better the prognoses would be that are based on that theory, (Friedman 1953). Similar but somewhat less extreme notions are found already in the work of Menger (1883) or Schumpeter (1908), and currently in the methodological positions of, for example, Niehans (1989) or Lazear (1995). The results of these methodological positions are highly idealized models which are based on the simplest behavioural premises and something essential for the instrumentalist attitude - the researchers themselves demonstrate a great disinterest in the improvement of their theoretical base upon which their models are built, (Arni 1989). In particular they do not attempt to test their basic theoretical premises empirically and severely.

\section{Methodological Errors}

From a philosophical point of view nothing speaks for instrumentalism, (Popper 1962; Musgrave 1981; Vollmer 1991). The assertion that theoretical concepts need no realistic indication proves obsolete even when trying to do what instrumentalists think is the main task of science: namely inferring prognoses from theories, (Albert 1987). For this it is necessary to connect the theoretical propositions with propositions about the empirical data, (the antecedence conditions). This on purely logical grounds is only meaningful if the theoretical and the empirical propositions have the same semantic. One of the insights that will survive the philosophical controversies over positivism will be that there is no such thing as pure data, i.e. that any observational statement is a theoretical statement too and can only be understood with the backing of some theory, (Popper 1935, 1962). In any concrete application, viz. any prognosis, theoretical and empirical propositions have to be connected in a logically correct manner. This requires the propositions to have the same theoretical status. But in the instrumentalists' view there are propositions denied of any realistic meaning (the theory) and propositions which have an obvious counterpart in reality, (the observational propositions). This is anything but convincing, (regarding the construction of theories and their modes of applications, c.f. Bunge 1967). A second significant argument against instrumentalism results from the abandonment of insight that it implies, because: “... without the assumption that there do exist some natural laws, the possibility of prognoses remains a puzzle" (Albert 1987, 63). Feyerabend (1964) also makes clear that instrumentalism has striking weaknesses, but he insists that realism, too, cannot endure in a strict sense. This is evident if one reflects on the process of concrete scientific research. For example the resistance against the theory of Copernicus, (which holds that the earth turns around the sun), is understandable if one considers the scientific knowledge prevailing at the time Copernicus lived. It was very plausible to see in his theory nothing other than yet one more mathematical scheme for computing the movements of the planets, because the new heliocentric perspective collided with many facts and laws which counted as true: "The argument ... shows that considering these facts and these laws the hypothesis cannot be true, that it can at most be an 
instrument of prediction" (Feyerabend 1964, 289). ${ }^{4}$ This problem exists in the behavioural sciences too. Here instrumentalistic beliefs are hidden often in auxiliary assumptions, (which come into play in any application of a theory), and for which no realistic interpretations are offered. To understand this, one has to consider that any scientific explanation is based on an explanation model. Therefore one can say with some reason: "As long as one can explain the interesting phenomena, there are no reasons to see any problem in [...] unrealistic model premises - even if they are known as wrong" (Esser 1993, 133). The problem lies in the complexity that an explanation model can have. If one wants to explain, for example, why the threshold to hire new employees in a concrete firm is very high, one would have to consider the values and expectations of all decision-makers involved, the decision structures, the definition of the problem, and much more, in order to offer a "complete" explanation. But from the necessary simplifications, (which are based clearly on problems of specification and precision), no prinicipal difficulties result, because they can be replaced by more realistic assumptions if ever they prove to be indefensible and not very robust. This "local instrumentalism" therefore creates no problems at all, (Musgrave 1981). Problems arise if one "immunizes" the core theoretical assumptions with the argument that simplifications cannot be avoided, as demonstrated in the following quotation: "In the first stage of model building the simplest behavioural theory is to be chosen: the theory of utility maximization or the rule of rational choice” (Esser 1993, 135).

\section{Methodological consequences}

It is not surprising that researchers with such attitudes are not interested in the elaboration (or even the refutation) of their theories. They see their task and mission to look for new applications for their critic-immune theories, (and they surely find them). As a result, for example, new fields of "rational choice" and "economics" emerge time and time again. You can find economics of politics, economics of law, economics of lobby groups, and an economic theory of community, of family, of law and of media. They do research into education economics, personnel economics, organizational economics, information economics etc., etc. The pleasure is a mixed one, however, for the central figure of economic theory - "homo oeconomicus" or "homo rationalis" because it becomes the leader of a gang of seedy henchmen: the rational cheaters and liars, the rational criminals, and - a paragon of virtue for compensation - the rational altruists, (Cornish 1986; Van de Kragt/Dawes/Orbell 1988; Molho 1997). Regarding the contents, however, there is nothing particularly exciting. The so-called personnel economics, (Parsons 1986; Milgrom/Roberts 1992; Backes-Gellner/Lazear/Wolff 2001; Sadowski 2002; for a discussion see Alewell 1996; Weibler 1996), makes many new discoveries of long known phenomena, which in the sallow light of economic theory seem somewhat strange if not to say surreal. Some researchers try to connect behavioural concepts with the economic calculus. For example Frank (1990) examines

Feyerabend uses two examples from quantum theory to show that this problem also arises in modern physics, namely that alternative "realistic" theories are better at explaining a new phenomenum than previous instrumentalistic theories, but that the new theories have problems with other facts and therefore also have to be described as wrong or unrealistic. 
why teams can be stable even if the abilities of their members differ. This seems problematic in the light of the well known fact that nobody wants to possess a low status, (whereby Frank equates status rank with ability rank). Actually only status homogenous groups should emerge. Frank explains the stability of status heterogeneous groups with the help of two assumptions. Firstly that persons with lower abilities (and therefore low status) trade the deprivation of the satisfaction of their status needs for financial return. Secondly that those with higher ability sacrifice some of the wages they could get and give it to their less able companions for the sake of gaining obeisance. If, however, one considers the enormous importance of social status for people's self-identity and in their joint decision-making, (Cooley 1922; Mannix 1993, Ridgeway 1993), such a superficial view of the world as Frank displays is somewhat baffling. ${ }^{5}$

It is certainly no secret to its adherents that the standard economic theory is wrong. Thus they would not be particularly concerned if advised of the countless defects of decision-making (Kahneman/Slovic/Tversky 1982; Goldstein/Hogarth et al. 1997). One reason why so few economists are disturbed by the proof of the weak rational capabilities of human beings may lie in the fact that it is always possible to explain the results which contradict the rational theory. One way to "save" the rationality assumption is to make some supplementary suppositions (e.g. about the information a decision-maker has) or to postulate a suitable utility function. Another explanation for the resistance to empirical critics is clearly derived from rational choice theoreticians' missing aspiration to make realistic propositions. They see in their theories only analytical instruments. A third reason for the coldness towards behavioural insights comes from the conviction economists have that the only important things to consider within the realm of economics are the laws of the economy to the exclusion of all others. It seems to be no accident that many prognoses that are based on economic theory prove to be true. Meyer $(2002,97)$ gives an important hint: "In my opinion one should investigate why the explanations of the economic theory often prove true even if one cannot trust many of their laws." His answer is that certain institutions, (such as property rights, competition, law, police and governmental administration), guide economic decision-making in such a way that the motive to maximize income gains a dominant position. The argument sounds persuasive, but it is beside the point. The question which should be posed instead is: what rules exist in economic life and why do human beings obey them? To formulate the problem in this way solves many puzzles. That the participants of economic life behave "economically" is rooted in the simple fact that they adapt their behaviour to the "rules of the game". The error that the proponents of rational choice approaches make, lies in the assumption that, with this, no further explanations of human behaviour are needed. But is this true? Does it suffice to know and spell the rules of economic and rational behaviour? Surely not. Firstly, other concepts of rationality are much better than the concept of rational-

5 It is interesting to see that the attempts to connect behavioural concepts with economic concepts almost always amount to a subsumption of the proper empirical insights under the rational principle. This applies even to researchers, who show the explicit willingness to open the rational choice paradigm and to change it (e.g. Esser 2002, Fehr/Falk 2002). 
ity of the rational choice approach. Secondly, there is no real exploration into which rules in the economy actually come into operation. Thirdly, it has to be made clear whether it actually pays off to follow them. Fourthly, these are not the decisive questions. If there is something like a "game of the economy" which follows certain "rational" rules, how this game can be shaped is not of primary interest. Much more important is the question of the conditions under which humans are prepared to play this game and whether they then follow their own rules.

\section{Methodological decisions}

In what way can the controversy between an instrumentalistic and a realistic position be resolved? Paul Feyerabend sees the solution in the attitude of the researchers, in the attitude of a "crank" on the one hand and that of a respectable thinker on the other: "... the distinction between the crank and the respectable thinker lies in the research that is done once a certain point of view is adopted. The crank is usually content with defending the point of view in its original, undeveloped, metaphysical form, and he is not at all prepared to test its usefulness in all those cases which seem to favor the opponent, or even to admit that a problem exists." (Feyerabend 1964, 305). With this Feyerabend refers to a methodological idea, namely the "principle of testability", according to which scientists should undertake stringent tests to examine their theories. The methodological conjecture on which this principle is based is that the scientific progress will show at one point which of the alternative hypotheses gives us a better picture of reality. This certainly does not disprove instrumentalism. And this is not surprising, because instrumentalism cannot be disproved. It will always be possible to interpret every knowledge in an instrumentalistic sense, (Colander 1991, Musgrave 1998). But it is quite difficult to avoid the impression that instrumentalism belongs to that selection of philosophical positions about which Bertrand Russell said one can not prove are definitely wrong, but, on the other hand, it is very difficult to find any reason why they should be right, (Russell 1912).

\subsection{Problem-orientation}

The behavioural approach of HRMS does not think in terms of scientific subjects (economic, psychological etc.) but has a strict focus on scientific problems. The starting points for theory development are concrete 'explanation' tasks. This is because the typical problems in HRM cannot be cut into slices and given to the various behavioural science disciplines to shed their specific light upon. What, for example, is the nature of the phenomenon that some employees buy shares in their company and others do not? Is this exclusively an economic problem? And the question as to why some supervisors are successful in motivating their subordinates to exert excessive effort: is this only a question of power, (and therefore a sociological problem)? What about the question as to why a firm prefers long-term employment relationships? Is this only a cultural problem? And, is the creative and innovative behaviour of an employee only a matter of personality? Obviously the questions in HRM are multifaceted, so they need very different theoretical stances to match. But frequently this is seen as problematic and the result is that more and more researchers demand to concentrate in HRMS on problems which are evidently (or mainly) economic problems. This is seen as advantageous because it would allow the restriction of the scientific 
task on the application of economic theories. But these suggestions are not really helpful as they are neither clear nor fertile. It is not even evident what are economic problems and what would be a genuine economic theory. The rational principle does not bring us further forward because this principle deals explicitly with practical action, (maximizing behaviour), and not with problems of explanation. Furthermore it is not convincing if a researcher were to restrict himself to the assumption that men and companies obey the rational principle. Similarly the sometimes heard advice to look at the essence of the economy is misleading because questions about the essences of a phenomenon cannot be answered and therefore the essential laws of the economy will stay a chimera. One comes very quickly, then, to views like that of Dieter Schneider who sees the aim of management theory, (more precisely: of "Betriebswirtschaftslehre"), to be to find out the best ways to maximize the income of the economic players. In the context of HRM the question naturally arises as to whose income should be maximized and it becomes clear very quickly that it is the capital return and not the income of the members of the company which is at stake. But even if one were to accept this narrow view, nothing would be gained because to influence the behaviour of the members of an organization, (those responsible for generating the capital return), one needs insights from the behavioural sciences. And the simple image of men which dominated the thinking of Frederick Winslow Taylor, (whose emphasis, as is well known, was on maximum productivity, c.f. Taylor 1913), is probably one no scientist would like to adopt. But it is not only the determination of genuine economic questions which causes trouble, the answers to the question of what is meant by a genuine economic theory remain nebulous too. Normally the rational theory is recommended here. However this theory- as already described above - is no real theory but, if anything, some kind of a maxim. If one tries nevertheless to give it a descriptive interpretation, then one gets into previously discussed difficulties because everybody knows that the rational choice theory is wrong and that it is not possible to explain human (and economic) behaviour. The researchers who use it do so because they think that there is no better theory, (which is wrong), or because they clearly do not aspire to develop true theories but are content with their instrumentalist striving. There are, naturally, limits to the content of the rational theory. So, for example, it makes no sense to use a purely cognitive theory that assumes hyper-rationality when studying emotional problems in teamwork. Certainly one can respond that such questions are not economic questions and therefore no legitimate theme within HRMS. The problemoriented view in a behavioural HRMS does not allow such an objection. Because problems concerning co-operation, (which often arise out of emotional problems), have immediate and sustainable economic consequences, they have to be investigated as part of an economic discipline anyway. In a behavioural HRMS all theories from all behavioural and social sciences have their place and of course economic theories have their place too - as long as they are helpful. A behavioural HRMS always uses theories with the greatest power of explanation, (unless they violate other essential scientific standards). 


\subsection{Complexity}

But with this the problem is not solved. It is not possible (and makes no sense) to employ a special theory for every question. The main purpose must be to solve the 'explanation' task in the best way. To do this it is normally necessary to use more than one theory and to integrate their propositions into an explanation model, (c.f. in detail Martin 2001). To explain the fact that some firms have a high, and other firms a low employment threshold, for example, one should use, simultaneously, theoretical elements of transaction cost economics, sociological institutional theory, and behavioural decision theory. In doing such integrative research it is not impossible, (indeed would be desirable), for a new theoretical stance to arise, which is not only able to explain the employment threshold, but can explain other aspects of the employment behaviour of companies as well, (Martin 2004). But the main point is that complexity in itself does not provide an argument to use only specialized and unconnected theories. The 'explanation' task always has to be performed with the help of explanation models and these models deliver the platform to integrate ostensibly divergent theoretical elements into a coherent pattern. To be certain, a prerequisite for this task is to explore carefully all conceivable relationships between different theoretical propositions. Doing this, however, opens up the opportunity for fertile development of more integrative theories.

\section{Strengths of a behavioral HRMS}

A behavioural HRMS is firstly a success story. Secondly, it has great practical importance, and thirdly, it is valuable in the sense of "enlightenment": the liberation from immaturity which finds expression in narrow-minded world views, prejudice and superstition.

\subsection{Insights}

The behavioural HRMS can resort to a richness of consolidated findings about working men and their work relationships. But the behavioural HRMS should not be confounded with applied organizational behaviour research, (as documented for example by Locke 2000). Instead it uses insights into all the players, (employees, managers, owners), and into all behavioural levels, (individual, group, organizational), and it has a behavioural as well as a systems perspective. When talking about science one thinks primarily about elaborated and well formulated theories, but beside this "core" of science exists valuable and diverse knowledge, (Martin 2001). One great merit of the scientific endeavour is that it drives attention to significant phenomena which determine behavioural processes. An example of great importance for HRM is the notion of intrinsic motivation, (Deci/Ryan 1985). Another is the role of positive affect in work behaviour, ("feeling good, doing good", George/Brief 1992). Even if the empirical laws of these or similar phenomena are not well understood, they deserve recognition and intensive debate. Of great value also are the many empirical generalizations, which were identified by the theoretical and empirical research. To mention but two, there is the "groupthink" syndrome, (Janis 1972), and - taking a further example of group behaviour - the effects which emerge from group composition, (such as the motivational corruption effect which comes from great differences in the achievement moti- 
vation of group members, Martin 1998). Furthermore there are many empirically proven law-like propositions. An example is the robust association between certain attributes of a task, (such as significance, autonomy and feedback), and job satisfaction, (Hackman/Oldham 1980). A second example is that it is well known that massive time pressure can lead to hyper-vigilance, (an attention overload which blocks rational reasoning, c.f. Janis/Mann 1977). This example seems to be very distant from the problems a HRMS has to handle. But the opposite is true as is shown by the study of Bourgeois/Eisenhardt (1988), whereby it pays for a management team not to submit to behavioural pressure but to buy additional time, even if this leads in turn to even more time pressure, (c.f. also Bronner 1982). This effect is a good example of a module which should be used in a general micro theory of decision-making. The further elaboration of such a theory would be very valuable. Strangely enough in HRMS only few research efforts are directed to develop basic behavioural theories. Theoretical considerations mostly follow the so-called SEU-paradigm, (SEU: subjectively expected utility). According to this paradigm, humans always select the behaviour which promises them the utmost utility. It is true that some SEU theories are highly differentiated, (Hollenbeck/Klein 1987; Katzell/Thompson 1990), yet despite this they do not really move from their static viewpoint, (that is that the various positive and negative utilities of an act are summed in a more or less transparent fashion), and they don't contain any propositions about the volitional process itself. ${ }^{6}$ Interestingly enough, a theory that has existed for almost half a century may serve as the core of a genuine process theory, namely the March-Simon "model of motivated behaviour", (March/Simon 1958). Janis/Mann's above-mentioned conflict theory of decision-making could amongst some other theories which deal with other parts of the decision process - be integrated very well in the basic theory of March and Simon, (for other process theories of human behaviour c.f. Dörner 1999; Kuhl 2001). Finally, another important aspect of a behavioural HRMS should be mentioned which deals with the diffusion of scientific insights into the awareness of managers and employees. The resulting background knowledge probably has the greatest practical impact and is perhaps the most significant indicator as to whether HRMS fulfils its enlightenment function. Certainly HRMS has great deficits in this respect. Two examples may suffice as illustration. For a long time researchers tried to develop tools which would allow supervisors to influence and direct their subordinates. The many attempts to demonstrate the efficacy of such tools did not deliver any convincing results. Regrettably this wisdom has yet to get around. Against all scientific insights the message put across in leadership seminars is still that it depends on the right 'tricks' on the part of a supervisor to infuse motivation, loyalty and satisfaction. It would be a great step forward if people were to notice that it is more important to invest in the quality of the supervisor/subordinate relationship than to trust in behavioural techniques, (Graen/Uhl-Bien 1995). Similar considerations apply to the image of man that stands behind the application of HRM tools. It is not new that men do not all have the same motivational structure (e.g. they are not all primarily or even exclusively economically motivated, c.f. already Spranger 1923), nor is it new that motive structures apply to simple schemata (c.f. the so called

6 Curiously SEU-Theories often are called process theories (especially in textbooks). 
"complex man", Schein 1980). It is all the more odd, therefore, that even researchers of HRMS revert to this not really very exciting insight.

\subsection{Practice}

Practitioners have to act in a real world which is indivisible. Although it is possible to think of reality in a fragmented, analytical way, it is not possible to live in a world dissected in such a way. If, therefore, one wants to shape the world in an enlightened sense, one should consider the entirety and complexity of the problem situation. In so far as HRMS is seen as an applied science, it should therefore provide the knowledge necessary to cope with the problems of HRM. The weight which is given to specialized pieces of knowledge varies of course dependent upon the question at stake. But to consider only one (e.g. the economic or the psychological) aspect in relation to a concrete task in HRMS is an ideological position and contradicts the ethos of an applied science (Martin 2001).

\subsection{Enlightenment}

A basic motive of scientific endeavour lies in the striving for an enlightened society. Does the behavioural HRMS meet this maxim? There is no general answer to this question because the use of knowledge does not follow the production of knowledge, but insofar as the behavioural HRMS increases our knowledge it makes a contribution to enlightenment because better knowledge corrects wrong beliefs and sheds light on our blind spots. A striking example of the prejudice-reducing function of knowledge comes from motivation research. For a long time it was a widespread opinion in the United States that Blacks should have a lesser achievement motivation than Whites. But the ostensible, race-related difference in achievement motivation really does not exist. The achievement motivation is just expressed in different ways and in different fields which are open or closed for parts of the population as a result of institutional arrangements (Maehr 1974). Another example stems from the sixties when a large number of so-called "guest workers" from Southern Europe were employed in Germany. The dominant belief was that the "guests" would stay only for a short period and, in particular, would leave their family at home. Both conclusions were based on callow motivational assumptions. The so called experts of labour policy should most certainly have known better. This example illustrates, by the way, how enlightenment cannot be equated with expert advice and consultation - especially not in the contested terrain of HRM. It is difficult even for scientists to keep in mind the limits of their knowledge and to avoid partiality. This is evident from glimpses into the HRM "recipes for success" which are regularly promoted to companies. Enlightenment is gained only if knowledge becomes part of daily discourse and if it becomes impossible for a blinkered view of what is a complex reality to dominate actions in practice. Enlightenment is often far from the agenda when experts get involved.

\section{Final remark: The need for self-reliance}

In recent years the need to give the HRMS a more distinct profile has been articulated over and over again. Quite a few colleagues want to establish a "genuine" economic discipline and they demand to use primarily economic theories in the field of HRMS, both for descriptive as well as for normative ends. Against this a behavioural HRMS 
looks for the best available knowledge to explain HRM phenomena. In light of this aim the complaint about missing economic elements in HRMS, (Wunderer/Mittmann 1983; Sadowski et al. 1994), sounds curious. If economic theories enrich knowledge they are, of course, welcome. But if they occupy the field of HRMS and restrict the access of other theories to its realm, then this should not be allowed. But one does not need to be in great fear about this because if HRMS were to be transformed into a socalled genuine economic discipline, the HRM questions would be answered by researchers from outside the economic and management disciplines. This is a consequence that economists who are concerned with the shape of their discipline, (and the access to research fields and research funds), should consider. And as to the argument that a HRMS needs an intellectual habitat, (and therefore as an economic theory must be connected with the rational principle), well, it is remarkable in the first place that no one is looking at it from another angle. HRMS is confronted with phenomena in need of quite another concept of rationality from that supplied by economics, and all disciplines, (especially economic ones), could profit from this insight.

But much more problematic than the question of whether or not it is good to establish strict frontiers between scientific disciplines is the danger, as was described above, of changing from a realistic to an instrumentalistic position. An instrumentalist's HRMS has no interest in theories which explain the deep structure of reality. Instead it "uses" theories to create the impressions its adherents expect to see. This is not true science but an impoverishment of science to be avoided by any economist worthy of that title.

\section{References}

Albert, H. (1987): Kritik der reinen Erkenntnislehre. Tübingen: Mohr Siebeck.

Albert, Hans (1979): Realität und Wahrheit. In): Zeitschrift für philosophische Forschung, 33, 567-587.

Albert, H. (2002): Varianten des kritischen Rationalismus. In: Böhm, J.M./Holweg, H./Hoock, C. (Eds.): Karl Poppers kritischer Rationalismus heute, 3-24.Tübingen: Mohr Siebeck.

Alewell, D. (1996): Zum Verhältnis von Arbeitsökonomik und Verhaltenswissenschaften. In: Die Betriebswirtschaft, 56, 667-683.

Arni, J.L. (1989): Die Kontroverse um die Realitätsnähe der Annahmen in der Ökonomie. Grüsch: Rüegger.

Backes-Gellner, U./Lazear, E.P./Wolff, B. (2001): Personalökonomik. Stuttgart: Schäffer-Poeschel.

Böhm, J.M./Holweg, H./Hoock, C. (2002) (Eds.): Karl Poppers kritischer Rationalismus heute. Tübingen: Mohr Siebeck.

Bourgeois, L.J./Eisenhardt, K.M. (1988): Strategic Decision Processes in High Velocity Environments. In: Management Science, 34, 816-835.

Bronner, R. (1982): Decision Making under Time Pressure, Lexington: Lexington Books.

Bunge, M. (1967): Scientific Research. Berlin: Springer.

Caldwell, B. (1982): Beyond Positivism. Economic Methodology in the Twentieth Century. London: Allen und Unwin.

Colander, D. (1991): Why aren't Economists as Important as Garbagement. New York .

Cooley, C.H. (1922): Human Nature and the Social Order. New York: Charles Scribner's Sons.

Cornish, D.B. (1986) (Ed.): The Reasoning Criminal. New York: Springer.

Deci, E.L./Ryan, R.M. (1985): Intrinsic Motivation and Self-Determination in Human Behaviour. New York: Plenum Press.

Dettmann, U. (1999): Der Radikale Konstruktivismus. Tübingen: Mohr Siebeck.

Dörner, (1999): Bauplan für eine Seele. Reinbek: Rowohlt. 
Esser, H. (1993): Soziologie. Frankfurt a.M.: Campus.

Esser, H. (2001): Soziologie. Spezielle Grundlagen. Band 6: Sinn und Kultur. Frankfurt a.M.: Campus.

Fehr, E./Falk, A. (2002): Psychological Foundations of Incentives. In: European Economic Review, 46, 687-724.

Festing, M. et al. (2004): Personaltheorie als Beitrag zur Theorie der Unternehmung. München: Hampp.

Feyerabend, P.K. (1964): Realism and Instrumentalism. In: Bunge, M. (Ed.): The Critical Approach to Science and Philosophy, 280-308. London: Free Press of Glencoe.

Frank, R. H. (1990): Rethinking Rational Choice. In: Friedland, R./Robertson, A.F. (Eds.): Beyond the Marketplace, 53-88. New York: Aldine de Gruyter.

Friedman, M. (1953): Essays in Positive Economics. Chicago .

George, J.M./Brief, M.P. (1992): Feeling good - doing good. In: Psychological Bulletin, 112, 310-329.

Goldstein, W.M./Hogarth, R. (1997): Research on Judgement and Decision Making. Cambridge: Cambridge University Press.

Graen, G.B./Uhl-Bien, M. (1995): Relationship-based Approach to Leadership. In: Leadership Quarterly, 6, 219-247.

Hackman, J.R./Oldham, G.R. (1980): Work Redesign. Reading: Addison-Wesley.

Hollenbeck, J.R./Klein, H.J. (1987): Goal Commitment and the Goal-Setting Process. In: Journal of Applied Psychology, 72, 212-220.

Janis, I. (1972): Victims of Groupthink. Boston: Houghton, Mifflin.

Janis, I./Mann, L. (1977): Decision Making. New York: Free Press.

Kahneman, D./Slovic, P./Tversky, A. (1982) (Eds.): Judgement under Uncertainty. New York: Cambridge University Press.

Katzell, R.A./Thompson, D.E. (1990): An Integrative Model of Work Attitudes, Motivation and Performance. In: Human Performance, 3, 63-85.

Klimecki, R./Gmür, M. (1998): Personalmanagement. Stuttgart: Lucius und Lucius.

Kuhl, J. (2001): Motivation und Persönlichkeit. Göttingen: Hogrefe.

Lazear, E.P. (1995): Personnel Economics. Cambridge: MIT Press.

Lenk, H. (1978): Wissenschaftstheorie und Systemtheorie. In: Lenk, H./Ropohl, G. (Eds.): Systemtheorie als Wissenschaftsprogramm, 239-261. Königstein: Athenäum.

Locke, E. (2000) (Ed.): The Blackwell Handbook of Principles of Organizational Behavior. Oxford: Blackwell.

Maehr, M.L. (1974): Culture and Achievement Motivation. In: American Psychologist, 29, 887-896.

Mannix, E.A. (1993): Organizations as Resource Dilemmas. In: Organizational Behaviour and Human Decision Processes, 55, 1-22.

March, J.G./Simon, H.A. (1958): Organizations. New York: Wiley.

Martin, A. (1988): Personalforschung. München: Oldenbourg.

Martin, A. (1998): Affekt, Kommunikation und Rationalität in Entscheidungsprozessen. München: Hampp.

Martin, A. (2001): Personal. Stuttgart: Kohlhammer.

Martin, A. (2004): Die Leistungsfähigkeit der Anreiz-Beitrags-Theorie. In: Festing, M. et al. (Eds.): Personaltheorie als Beitrag zur Theorie der Unternehmung, 13-42. München: Hampp.

Menger, C. (1883): Untersuchungen über die Methode der Sozialwissenschaften und der politischen Ökonomie insbesondere. Leipzig: Duncker und Humblot.

Meyer, W. (2002): Grundlagen des ökonomischen Denkens. Tübingen: Mohr Siebeck.

Milgrom, P./Roberts, J. (1992): Economics, Organization and Management. Englewood Cliffs: PrenticeHall.

Molho, I. (1997): The Economics of Information: Lying and Cheating in Markets and Organizations. Oxford: Blackwell.

Musgrave, A. (1981): Der Mythos vom Instrumentalismus in der Astronomie. In: Duerr, H.P. (Ed.): Versuchungen. Band 2, 231-279. Frankfurt a.M.: Suhrkamp.

Musgrave, A. (1998): Putnams modell-theoretisches Argument gegen den Realismus. In: Gadenne, V. (Ed.): Kritischer Rationalismus und Pragmatismus, 177-201. Amsterdam: Rodopi. 
Niehans, J. (1989): Klassik als nationalökonomischer Mythos. In: Zeitschrift für Wirtschafts- und Sozialwissenschaften, 109, 1-17.

Parsons, D.O. (1986): The Employment Relationship. In: Ashenfelter, O./Layard, R. (Eds.): Handbook of Labor Economics. Band 2, 789-848. Amsterdam. Elsevier Science.

Popper, K.R. (1935): Logik der Forschung. Wien. Springer.

Popper, K.R. (1962): Conjectures and Refutations. New York. Basic Books.

Probst, G. (1993): Organisation. Landsberg: Verlag Moderne Industrie.

Ridder, H.G. (1999): Personalwirtschaftslehre. Stuttgart: Kohlhammer.

Ridgeway, C. (1993): Legitimacy, Status, and Dominance Behavior in Groups. In: S. Worchel/ J.A. Simpson (Ed.): Conflict Between People and Groups (110-127). Chicago: Nelson-Hall Publishers.

Rusch, G. (2002): Konstruktivismus in den Wirtschaftswissenschaften, in Marketing und Management. Frankfurt a.M.: Suhrkamp.

Russell, B. (1912): The Problems of Philosophy. London: Williams and Norgate.

Sadowski, D et al. (1994): Weitere 10 Jahre Personalwirtschaftslehre - ökonomische Silberstreif am Horizont. In: Die Betriebswirtschaft, 54, 397-410.

Sadowski, D. (2002): Personalökonomie und Arbeitspolitik. Stuttgart: Schäffer-Poeschel.

Schanz, G. (2000): Personalwirtschaftslehre. München: Vahlen.

Schein, E.H. (1980): Organisationspsychologie. Wiesbaden: Gabler.

Schneider, D. (1987): Allgemeine Betriebswirtschaftslehre. München: Oldenbourg.

Schumpeter, J.A. (1908): Das Wesen und der Hauptinhalt der theoretischen Nationalökonomie. Leipzig: Duncker und Humblot.

Spranger, E. (1923): Lebensformen, 3. Auflage. Halle: Niemeyer.

Staehle, W./Conrad, P./Sydow, J. (1999): Management. 8. Auflage. München: Vahlen.

Stegmüller, W. (1973): Theorie und Erfahrung. 2. Halbband. Theorienstrukturen und Theoriendynamik. Berlin: Springer.

Taylor, F.W. (1913): Die Grundsätze wissenschaftlicher Betriebsführung. München: Oldenbourg) .

Van de Kragt, A./Dawes, R./Orbell, J. (1988): Are People who Cooperate Rational Altruists? In: Public Choice, 56, 233-247.

Vollmer, G. (1991): Wider den Instrumentalismus. In: Bohnen, A. (Ed.): Wege der Vernunft, 130-150. Tübingen: Mohr Siebeck.

Weber, W. (1996) (Ed.): Grundlagen der Personalwirtschaft. Wiesbaden: Gabler.

Weibler, J. (1996): Ökonomische vs. verhaltenswissenschaftliche Ausrichtung der Personalwirtschafslehre - Eine notwendige Kontroverse? In: Die Betriebswirtschaft, 56, 649-665.

Wunderer, R./Mittmann, J. (1983): 10 Jahre Personalwirtschaftslehre - von Ökonomie nur Spurenelemente. In: Die Betriebswirtschaft, 43, 623-655. 